\title{
Pengalaman Penderita Skizofrenia tentang Proses Terjadinya Halusinasi
}

\author{
Suryani \\ Fakultas Keperawatan Universitas Padjadjaran \\ E-mail:ynsuryani@yahoo.com
}

\begin{abstract}
Abstrak
Halusinasi adalah gejala khas skizofrenia yang merupakan pengalaman sensori menyimpang atau salah yang dipersepsikan sebagai sesuatu yang nyata. Kondisi ini menyebabkan individu tidak dapat kontak dengan lingkungan dan hidup dalam dunianya sendiri. Penderita skizofrenia dengan halusinasi yang masih kuat dapat berbahaya bagi dirinya sendiri dan orang lain. Hingga saat ini, mekanisme terjadinya halusinasi yang dialami penderita skizofrenia belum jelas. Penelitian yang dilakukan pada Desember 2007 hingga April 2008 ini bertujuan menggali pengalaman penderita skizofrenia tentang proses terjadinya halusinasi. Metode yang digunakan adalah kualitatif dengan pendekatan fenomenologi. Delapan orang responden yang memenuhi kriteria diwawancara secara mendalam dan seluruh pembicaraannya direkam dengan tape recorder. Hasil wawancara dianalisis dengan pendekatan Collaizi dan diperoleh lima tema besar yakni proses terjadinya halusinasi dimulai dengan serangkaian masalah yang dipikirkan atau dirasakan penderita, situasi atau kondisi tertentu dapat mencetuskan halusinasi, proses halusinasi terjadi secara bertahap, waktu proses halusinasi, dan pencegahan halusinasi dengan pendekatan spiritual serta penggunaan koping yang konstruktif. Berdasarkan hasil penelitian, dapat disimpulkan bahwa dalam merawat penderita skizofrenia yang mengalami halusinasi, perawat harus memahami bagaimana terjadinya halusinasi secara komprehensif.
\end{abstract}

Kata kunci: Fenomena, proses halusinasi, skizofrenia

\section{The Process of Hallucination as Described by People Diagnosed with Schizophrenia}

\begin{abstract}
Hallucination is one hallmark symptom of schizophrenia. Hallucination is false or distorted sensory experiences that appear to be real perception. This condition causes the individuals to lose contact with environment and live in their own world. They are also dangerous for other people and themselves because the hallucination threatens them. Until now, the phenomenon of hallucination have not been revealed yet. Therefore, it is important to explore the live world of the people who experience hallucination. The purpose of this research is to undertake an exploration of living with hallucination as described by people who have been diagnosed with schizophrenia. Phenomenological approach was used to gain data. The data was analysed using Collaizi' approach to analysis. Eight clients with schizophrenia were selected, and data were collected through audiotaped semistructured interviewes. Five main categories of theme emerged from the interviews: The process of hallicunation was started by a lot of problem that burdened the clients; the process of hallicunation was triggered by specific situation and condition; the process of hallucination was happened in several step, time for the process of hallucinations and hallucinations can be prevented by spiritual activity and constructive coping behaviour. Conclusions highlight the need to understand about the process of hallucinations comprehensifly.
\end{abstract}

Key words: Phenomenon, schizophrenia, the process of hallucinations 
Suryani: Pengalaman Penderita Skizofrenia

\section{Pendahuluan}

Pada tahun 2020 penyakit gangguan jiwa akan menjadi masalah utama di samping penyakit infeksi. Rossler, Salize, van Os , dan Riecher-Rossler (2005) menyatakan bahwa kesehatan jiwa telah menjadi "The Global Burden of Disease". Menurut data dari World Health Organization (2008) diperkirakan 24 juta orang di seluruh dunia akan mengalami skizofrenia dan di Indonesia penderita skizofrenia saat ini mencapai 1,2 juta.

Skizofrenia adalah suatu gangguan (psikosa) dengan gangguan utama pada proses berpikir, persepsi, kognisi, dan fungsi sosial (Elder, Evans, \& Nizette, 2005, p. 219). Halusinasi merupakan suatu gejala khas skizofrenia (Uhlhass \& Mishara, 2006). Individu dengan skizofrenia tidak dapat membedakan antara stimulus internal dan eksternal. Individu seolah-olah melihat atau mendengar sesuatu yang pada kenyataannya tidak ada. Menurut hasil penelitian Shawyer, dkk. (2008) individu yang mengalami halusinasi dapat berbahaya bagi dirinya sendiri maupun orang lain karena halusinasinya terkadang menyuruhnya untuk melakukan kekerasan. Carpenter (2004) mengemukakan hasil penelitianya menunjukan banyak sekali diantara penderita skizofrenia yang tetap mengalami halusinasi sekalipun mereka sedang mendapat obat-obatan anti psikotik.

Di Rumah Sakit Jiwa Cimahi walaupun belum ada kejadian bunuh diri, tetapi percobaan bunuh diri sering ditemukan pada penderita skizofrenia yang mengalami halusinasi. Di samping itu banyak penderita tersebut sering melakukan kekerasan pada barang atau orang lain. Keadaan tersebut tentunya perlu penanganan yang tepat dan serius dari tenaga kesehatan terutama perawat yang berada 24 jam bersama penderita.

Perencanaan terapi yang tepat dalam mengatasi perilaku penderita sangat penting. Oleh karena itu, pemahaman tentang bagaimana terjadinya halusinasi ini menjadi dasar yang sangat penting bagi perawat. Penelitian yang dilakukan oleh Whitfield, Dubeb, Felitti, dan Anda (2005) di San Diego dengan melakukan survei terhadap 50.000 penderita psikotik menemukan bahwa halusinasi yang dialami seseorang erat kaitannya dengan masalah yang menjadi pengalaman traumatis bagi dirinya. Menurut Garcelan (2004) ketika suatu proses halusinasi telah terjadi, maka pengalaman halusinasi berikutnya dicetuskan bukan oleh stres yang tinggi tetapi oleh kejadian pribadi tertentu dalam kehidupan individu yang menjadi fokus bagi dirinya.

Hasil penelitian yang telah peneliti lakukan pada tahun 2006, diperoleh hasil karekteristik halusinasi dari penderita skizofrenia. Jenis halusinasi terbanyak yang dialami penderita adalah halusinasi pendengaran (74,13\%). Penyebab halusinasi yang paling dominan adalah stres berat $(56,89 \%)$ dan umumnya terjadi pada saat penderita sedang sendiri atau menyendiri $(87,93 \%)$.

Penelitian mengenai pengalaman penderita skizofrenia ini secara umum menggambarkan karekteristik halusinasi yang dialami penderita skizofrenia. Pemahaman yang lebih mendalam tentang terjadinya halusinasi sangat diperlukan dalam mengungkap misteri dibalik kejadian halusinasi. Pemahaman tersebut menjadi penting untuk diteliti mengenai pengalaman penderita skizofrenia tentang terjadinya halusinasi.

Hasil penelitian ini dapat memberikan gambaran yang detail bagaimana proses terjadinya halusinasi yang dialami penderita skizofrenia. Hasil penelitian ini dapat menjadi masukan bagi tenaga kesehatan dalam merawat penderita skizofrenia

\section{Metode Penelitian}

Metode yang digunakanpada penelitianiniadalah kualitatif dengan pendekatan fenomenologi. Pada asalnya fenomenologi yang ditemukan oleh Hussler merupakan sebuah filosofi (Giorgi \& Giorgi, 2008). Fenomenologi tersebut lalu berkembang menjadi sebuah metode penelitian. Metode penelitian fenomenologi adalah suatu metode yang sistematis untuk mempelajari atau menggali sebuah fenomena yang sulit diobservasi atau diukur (Wilding \& Whiteford, 2005). Oleh karena itu, fenomenologi digunakan pada penelitian ini agar bagaimana terjadinya halusinasi dapat terungkap sebagaimana apa adanya. Responden dalam penelitian ini adalah delapan orang penderita skizofrenia yang sedang dirawat di ruang tenang Rumah Sakit Jiwa (RSJ) Cimahi selama periode Desember 2007 sampai April 2008. Responden 
Suryani: Pengalaman Penderita Skizofrenia

diwawancarai dua kali. Pertama di ruangan rawat RSJ Cimahi dan yang kedua di rumah responden. Pada wawancara pertama, informasi dikumpulkan dengan cara melakukan in depth interview (wawancara mendalam) terhadap responden yang memenuhi kriteria pada saat responden sedang dirawat di Rumah Sakit Jiwa Cimahi. Wawancara dilakukan selama 75 menit. Sebelumnya responden diberi tahu tentang tujuan dan kegunaan penelitian. Pertanyaan utama yang diajukan berupa pertanyaan terbuka. Pertanyaan-pertanyaan selanjutnya diajukan dengan maksud untuk mengklarifikasi atau memvalidasi informasi yang telah diberikan. Agar data yang terkumpul dapat terjaga dengan lengkap, maka wawancara yang dilakukan direkam. Peneliti juga membuat catatan yang bertujuan menuliskan keadaan atau situasi dan respons nonverbal yang ditunjukkan responden selama wawancara berlangsung. Wawancara yang kedua dilakukan di rumah partisipan. Wawancara kedua ini bertujuan untuk memvalidasi informasi yang telah ditranscribe oleh peneliti kepada partisipan.

Analisis data yang dilakukan menggunakan tujuh langkah menurut pendekatan Collaizi (1978), dimulai dengan mendeskripsikan semua hasil wawancara hingga terbentuknya struktur yang fundamental atau definisi dari pengalaman responden. Selama analisis data dilakukan, hal penting yang harus diperhatikan adalah bracketing. Selama proses analisis data tersebut, peneliti senantiasa fokus pada semua pernyataan yang responden ungkapkan dan mencoba membuang (put aside) semua pengetahuan, pengalaman, dan asumsi peneliti tentang aspek yang diteliti. Langkahlangkah yang telah dilakukan selama proses analisis data dilakukan secara berurutan sebagai berikut: pertama, mendeskripsikan hasil wawancara, kedua, membaca transkrip yang sudah dibuat berulang-ulang sampai diperoleh sense dari pengalaman partisipan, ketiga, menentukan pernyataan-pernyataan yang signifikan dengan mengacu pada tujuan penelitian, keempat, memformulasi meaning dari setiap pernyataan yang signifikan tersebut, keempat, mengorganisasikan pernyataanpernyataan yang signifikan serta meaningnya ke dalam cluster themes kemudian menentukan tema, setelah itu membuat dan menuliskan exhaustive description untuk setiap partisipan. Tahapan terakhir memvalidasikan tema dan exhaustive description kepada partisipan.

\section{Hasil Penelitian}

Hasil penelitian menunjukkan responden ke-1 usia 24 tahun, belum menikah, lulusan sekolah menengah atas, dan pertama kali didiagnosis mengalami skizofrenia tahun 2004. Responden ke-2 usia 35 tahun, status duda, lulusan sekolah menengah atas, dan telah mengalami skizofrenia dengan halusinasi yang sering sejak tahun 2001. Responden ke-3 usia 45 tahun, sarjana, dan tidak bekerja karena telah mengalami skizofrenia sejak tahun 1990. Responden ke-4 usia 55 tahun dengan tiga orang anak, tenaga administrasi di sebuah perusahaan swasta, dan mengalami skizofrenia sejak tahun 1996. Responden ke-5 usia 28 tahun, seorang janda beranak satu yang telah menderita skizofrenia sejak tahun 2001.

Responden ke-6 usia 29 tahun, pendidikan hingga sekolah menengah atas namun tidak tamat karena masalah biaya. Responden ke-7 usia 28 tahun, tidak memiliki pekerjaan tetap dan belum menikah. Responden ini sempat kuliah sampai tingkat III dan telah mengalami skizofrenia sejak tahun 1999. Responden ke- 8 usia 48 tahun, seorang suami dan buruh tidak tetap, menderita skizofrenia sejak tahun 1985. Penderita pernah kuliah tetapi gagal karena sering kambuh.

Hasil wawancara dengan delapan orang responden dapat diidentifikasi lima tema yang terdiri atas: terjadinya halusinasi dimulai dengan serangkaian masalah yang dipikirkan atau dirasakan penderita, situasi atau kondisi tertentu dapat mencetuskan halusinasi, halusinasi terjadi secara bertahap, dan proses dari pencetus sampai munculnya halusinasi terjadi dalam waktu yang relatif singkat. Halusinasi dapat dicegah dengan pendekatan spiritual, penggunaan koping yang konstruktif, dan menghindari kesendirian.

Pada tema ke-1, terjadinya halusinasi dimulai dengan serangkaian masalah yang dipikirkan atau dirasakan penderita.Halusinasi pada individu yang didiagnosis skizofrenia tidaklah terjadi begitu saja, akan tetetapi 
Suryani: Pengalaman Penderita Skizofrenia

disebabkan oleh berbagai masalah yang dialami oleh mereka. Hal ini sebagaimana diungkap oleh sebagian besar responden. Responden ke-1 yang sudah mengalami skizofrenia selama 8 tahun mengungkapkan: “...Waktu saya masih SMP, pertamanya saya pakai narkoba karena merasa kurang kasih sayang, saya dicuekkan sama orang tua. Orang tua saya bercerai. Bapak saya percaya yang gaib-gaib gitu, ketika saya nonton TV seolah ada yang memberi tahu...... memberi tahu bahwa saya tidak berguna".

Tidak seperti responden ke-1, responden ke-3 mengalami masalah yang cukup pelik dan kronik sehubungan dengan penyakitnya dan usianya yang sudah hampir setengah baya:

"Di rumah... saya melamun terus.... pingin punya istri... saya ribut sama orang bu, saya dianggapnya orang gila...... ribut karena memperebutkan perempuan. Saya kan punya pacar... pacar saya itu digangguin orang itu”.

Berbeda dengan responden ke-1 dan responden ke-3, responden ke-5 mengalami suatu pengalaman yang traumatis sebelum dia mengalami halusinasi seperti diungkapkannya:

"...saya dulu pernah diperkosa.... waktu saya kelas III SMP, saya sangat malu dan melamun.... kalau saya ingat peristiwa itu saya melamun... jadinya saya mendengar suara-suara”.

Responden ke-6 mempunyai pengalaman yang juga sangat menggelisahkan hatinya: “...Saya pingin kerja... tetapi tidak dapat. Tidak ada yang mau nerima saya. Jadinya saya gelisah dan mendengar suara-suara".

Responden ke-8 juga menyatakan kegagalan sebagai penyebab munculnya halusinasinya:

"...Saya gagal sekolahnya... terus kuliah di tempat lain... gagal lagi... akhirnya... saya sering melamun dan mendengar suarasuara".

Pada tema ke-2, situasi atau kondisi tertentu dapat mencetuskan halusinasi yang kemudian muncul adalah situasi atau kondisi tertentu yang mencetuskan munculnya halusinasi walaupun mereka sedang dalam pengobatan. Hal ini diungkapkan oleh semua responden dalam konteks yang berbeda, seperti yang diungkapkan oleh responden ke-1 pada peneliti berikut ini:

“...Ya, kalau saya lagi melamun, ingat-ingat peristiwa masa lalu, halusinasi saya suka muncul".

Tidak seperti responden ke-1, responden ke-2 mengungkapkan bahwa perasaan sedihlah yang memunculkan halusinasinya:

“...Saya pingin pulang, sedih, nggak enak.... pingin pulang terus".

Responden ke-3 mengungkapkan bahwa halusinasinya muncul setiap kali dia akan tidur:

“...Kalau malam, kalaumau tidur, melamun”.

Responden ke-4 mengungkapkan bahwa halusinasinya timbul kalau memikirkan sesuatu: “...Kalau lagi ada masalah dalam pikiran, pikiran saya lagi mampet maka halusinasi suka muncul ".

Responden ke-5 mengungkapkan dengan singkat: "...saya mendengar suara-suara kalau lagi melamun."

Seperti responden ke-5, responden ke-6 juga mengungkapkan: "...kalau saya lagi sendiri... melamun."

Responden ke-6 menambahkan: "Bila melamun.....misalnya waktu itu saya pingin punya mobil, rumah, kemudian dipikirkan seolah-olah ada imajinasi“".

Berbeda dengan yang diungkapkan responden ke-6, responden ke-8 mengungkapkan bahwa halusinasinya timbul kalau dia sedang marah seperti diungkapkannya:

“...nggak tau ya... kalau saya lagi kesal saya suka mendengar suara-suara" dan juga ketika dia merasa tersinggung seperti diungkapkannya "...perasaan tersinggung... perasaan tersinggung itu saya tekan akibatnya saya mendengar suara-suara".

Terjadinya halusinasi terjadi secara bertahap tidak tiba-tiba tetetapi terjadi melalui tahapan mulai dari situasi atau kondisi yang mencetuskan hingga munculnya halusinasi. 
Suryani: Pengalaman Penderita Skizofrenia

Tema ini muncul dari hasil analisis data terhadap terjadinya halusinasi yang dialami oleh sebagian responsden. Berikut ungkapanungkapan responden yang menunjukkan hal tersebut. Responden ke-3 mengatakan:

"Waktu itu... saya ribut sama orang... setelah ribut saya melamun. Setengah jam melamun muncul perasaan nggak enak...tegang... akhirnya muncul suara-suara".

Dalam konteks yang berbeda, responden ke-5 mengungkapkan tahapan proses halusinasi yang dialaminya:

"Kalau ingat peristiwa itu (diperkosa) saya jadi melamun...seperti kemasukan setan... hati terasa kosong, melayang-layang, kemudian muncul suara-suara".

Hampir sama dengan responden ke-5, responden ke-7 juga mengalami tahapan proses dimana masalah yang tidak terpecahkan menyebabkan individu melamun, kemudian merasa kosong dan mendengar suara-suara: "...hati gelisah...... melamun... misalnya waktu itu saya pingin punya mobil dan rumah, kemudian dipikirkan terus... melamun terus... pikiran jadi kosong... kemudian seolah-olah ada suara menimpali".

Terjadinya halusinasi ungkapan dari responden ternyata proses dari melamun sampai terjadi halusinasi itu tidak lama. Hanya berkisar antara 15 menit sampai satu jam responden ke-3 mengatakan:

"Dari saat melamun sampai munculnya halusinasi itu waktunya setengah jam kayaknya". Responden ke-6 juga mengungkapkan hal yang hampir sama "15 menit melamun, terus mendengar suarasuara itu. "Kemudian dia menambahkan:

"Nggak selalu ...tetapi rata-rata begitu".

Responden ke-7 mengalami waktu yang lebih lama dalam proses halusinasinya seperti diungkapkannya:

"Sekitar lima belas menitlah, ya, kira-kira begitulah... paling lama satu jam”.

Responden ke-4 tidak menyatakan waktu yang pasti dalam proses halusinasinya:

"Ketika ada masalah dalam pikiran... tidak lama saya langsung mendengar suara-suara itu”.
Berdasarkan hasil penelitian, pencegahan halusinasi dengan pendekatan spiritual dan penggunaan koping yang konstruktif, hal ini muncul dari hasil analisis data penelitian, semua responden mengungkapkan tentang cara yang dapat dilakukan untuk mencegah terjadinya halusinasi. Responden ke-1 yang telah mengalami halusinasi dalam waktu lebih dari 5 tahun mengungkapkan pengalamannya mencegah halusinasi:

"Sholat, banyak teman, curhat, jangan banyak pikiran”, Dengan informasi yang hampir sama responden ke-3 mengungkapkan "ditemanin gitu bu, diajak ngobrol, sholat, berdoa". Demikian juga dengan responden ke-7 "Rajin beribadah, konsultasi dengan tenaga kesehatan, sholat, puasa".

Responden ke-5 juga mengungkapkan hal yang hampir sama dengan responden ke-3 dan responen ke-7. Seperti berikut ini:

"Dulu saya sering banget mendengar suarasuara aneh. Tetapi sekarang sudah agak jarang. Saya sudah agak jarang mendengar suara-suara sejak saya mulai rajin sholat. Sekarang saya sholatnya tidak pernah ketinggalan lagi. Bahkan saya juga hampir tiap hari sholat duha. Terkadang juga sholat tahajjud.... Nah.. kalau malamnya saya sholat tahajjud siangnya saya tidak mendengar suara-suara yang aneh itu”.

Pencegahan halusinasi dengan pendekatan spiritual dan penggunaan koping yang konstruktif. Pencegahan halusinasi tersebut dapat muncul dari hasil analisis data penelitian, semua responden mengungkapkan tentang cara yang dapat dilakukan untuk mencegah terjadinya halusinasi. Responden ke-1 yang telah mengalami halusinasi dalam waktu lebih dari lima tahun mengungkapkan pengalamannya mencegah terjadinya halusinasi:

"Sholat, banyak teman, curhat, jangan banyak pikiran".

Informasi yang hampir sama responden ke-3 mengungkapkan:

"Ditemanin gitu bu, diajak ngobrol, sholat, berdoa". Demikian pula dengan responden ke-7 "Rajin beribadah, konsultasi dengan tenaga kesehatan, sholat, puasa".

Responden ke-4 mengungkapkan yang berbeda dalam mencegah halusinasinya yaitu 
Suryani: Pengalaman Penderita Skizofrenia

dengan mengendalikan pikirannya sendiri:

"Mengendalikan pikiran, kalau ada pikiran yang jelek-jelek buang jauh-jauh”.

Demikian pula dengan responden ke-8, yang menambahkan pengelolaan perasaan di samping pengendalian pikiran "Jangan banyak pikiran...jangan suka menekan perasaan, jaga perasaan supaya tetap tenang, sabar...".

\section{Pembahasan}

Hasil penelitian menunjukkan bahwa sebelum penderita mengalami halusinasi, mereka mengalami banyak masalah yang tidak teratasi. Masalah-masalah tersebut antara lain merasa kurang kasih sayang karena orang tua bercerai, ingin punya istri tetapi tidak ada yang mau, bermasalah dengan orang karena memperebutkan perempuan, diperkosa, sulit mendapat pekerjaan, serta gagal sekolah dan kuliah.

Berdasarkan pengalaman peneliti selama membimbing dan merawat pasien skizofrenia, memang semua penderita mengalami banyak sekali masalah akibat berbagai peristiwa yang terjadi dalam kehidupan mereka sejak mereka masih kanak-kanak sampai mereka dewasa. Masalah-masalah yang menumpuk dan tidak terpecahkan mengakibatkan mereka menjadi putus asa, melamun, dan akhirnya mengalami halusinasi.

Temuan ini sesuai dengan hasil penelitian sebelumnya yang dilakukan oleh Whitfield, dkk. (2005) yang menemukan bahwa halusinasi yang dialamipenderita skizofrenia eratkaitannya dengan masalah yang menjadi pengalaman traumatis bagi dirinya. Hasil penelitian O'Daly, Frangon, Chitnis dan Shergill (2007) mengungkapkan hal yang berbeda, hasil penelitian tersebut, penyebab terjadinya skizofrenia yang salah satu gejalanya halusinasi berhubungan dengan gangguan neurobiologi.

Setiap orang pasti mempunyai masalah, akan tetapi tidak semua orang yang mempunyai masalah mengalami gangguan jiwa sampai mengalami halusinasi. Gangguan tersebut terjadi bergantung pada seberapa besar masalah yang dihadapi dan bagaimana seseorang menyikapinya. Gangguan tersebut juga dipengaruhi oleh faktor lain seperti faktor psikoedukasi dan neurobiologi (Behrendt \& Young, 2004).

Perawat jiwa mempunyai peranan penting untuk melaksanakan program preventif di masarakat. Deteksi dini terhadap penderita gangguan jiwa sangat penting agar penderita dapat segera ditanggulangi dan penderita dapat disiapkan dengan koping yang baik, sehingga mampu menyikapi masalah penderita dengan baik pula.

Halusinasi terjadi tidak secara terus menerus tetetapi secara intermiten. Hanya sedikit dari penderita skizofrenia yang mengalami halusinasi selama 24 jam, sehingga dapat dikatakan bahwa ada hal yang dapat mencentuskan munculnya halusinasi. Jadi ada sesuatu yang mencetuskan munculnya halusinasi. Berdasarkan wawancara dengan responden, hampirsemuanya mengungkapkan bahwa ada situasi dan kondisi tertentu yang mencetuskan munculnya halusinasi. Situasi dan kondisi tersebut antara lain teringat peristiwa masa lalu yang menyakitkan, sedih, malam hari sebelum tidur, melamun, ada masalah, keadaan kesal, dan perasaan tersinggung. Temuan ini mendukung hasil penelitian sebelumya yang menyimpulkan bahwa situasi atau pikiran-pikiran tertentu dapat mencetuskan munculnya halusinasi (Garcelan, 2004).

Fenomena yang ditemukan di atas sangat besar kontribusinya dalam merawat penderita skizofrenia yang mengalami halusinasi. Temuan tersebut dapat dijadikan dasar untuk mencegah halusinasi. Pencegahan halusinasi dapat dilakukan dengan cara penderita harus menghindari situasi atau kondisi tersebut diatas. Implikasinya dalam asuhan keperawatan jiwa adalah sangat penting diingat agar dalam melakukan pengkajian, tidak mengungkitungkit masa lalu klien yang menyakitkan karena hal itu dapat mencetuskan munculnya halusinasi. Banyak sekali kasus yang terjadi di rumah sakit jiwa, penderita mengamuk setelah di-interview.

Telah diketahui dari hasil penelitian ini bahwa halusinasi tidaklah tiba-tiba tetapi terjadi melalui tahapan mulai dari situasi atau kondisi yang mencetuskan hingga munculnya halusinasi. Wawancara yang telah dilakukan terhadap semua responden, tidak satupun 
Suryani: Pengalaman Penderita Skizofrenia

yang mengungkapkan tahapan halusinasi seperti yang disimpulkan oleh Peplau (1952) dan Clack (1962) dalam Antai-Otong (1995). Ada responden yang menyatakan bahwa halusinasi yang dialaminya tidak pernah menyuruh-nyuruh dia melakukan sesuatu, hanya suara orang lagi berbicara. Ada juga yang hanya mendengar suara angin. Sebaliknya, ada juga yang secara langsung mendengar suara-suara yang menyuruh melakukan sesuatu tanpa melalui tahap conforting, condemning, dan controlling.

Implikasinya terhadap keperawatan jiwa adalah bahwa dalam merawat penderita yang mengalami halusinasi, tidaklah begitu penting untuk melakukan pemutusan halusinasi dengan mengatakan 'stop saya tidak mau dengar' seperti yang selama ini diajarkan oleh perawat di hampir semua rumah sakit jiwa di Indonesia. Hal yang terpenting adalah bagaimana mencegah agar penderita tidak mengalami halusinasi yaitu dengan cara melatih penderita untuk mengenali situasi dan kondisi yang mencetuskan halusinasinya dan mengajarkan penderita cara untuk mengatasi situasi atau kondisi yang mencetuskan halusinasinya tersebut. Tentu saja situasi dan kondisi yang mencetuskan halusinasi tiaptiap penderita berbeda-beda. Karena itu perlu pengkajian yang tepat dan akurat.

Proses dari pencetus sampai munculnya halusinasi terjadi dalam waktu yang relatif singkat. Temuan ini mungkin merupakan temuan yangterbaru dari proses terjadinya halusinasi karena belum ditemukan literatur lain yang mengungkap tentang waktu proses munculnya halusinasi. Hasil penelitian ini mengungkap bahwa proses munculnya halusinasi dari pencetus sampai timbul halusinasi tidak lama. Halusinasi muncul begitu ada situasi atau kondisi yang mencetuskan munculnya halusinasi tersebut, oleh karena itu, penting untuk mengenali dan mengendalikan situasi kondisi tersebut.

Halusinasi dapat dicegah dengan pendekatan spiritual, penggunaan koping yang konstruktif, dan menghindari kesendirian. Hasil penelitian ini mengungkap bahwa pendekatan spiritual dapat dilakukan untuk mencegah halusinasi sesuai dengan penelitian sebelumnya oleh Mohr, Brandt, Borras, Gillieron, dan Huguelet (2006) di
Genewa yang menemukan bahwa dari 115 responsden (penderita skizofrenia) yang terlibat dalam penelitian mereka, $71 \%$ menggunakan pendekatan spiritual untuk mencegah halusinasi mereka. Penderita spiritual tersebut disebabkan oleh mayoritas orang Indonesia yang mayoritas beragama Islam. Halusinasi ada hubungannya dengan keyakinan agama seseorang, misalnya pada penelitian ini responden mengungkapkan bahwa suara yang didengarnya berupa suara setan. Melalui pendekatan spiritual, yang dalam konteks penelitian ini dengan melakukan sholat dan berdoa, responden mampu mencegah munculnya halusinasi mereka. Kepercayaan bahwa kedekatan dengan Allah mampu mengusir setan telah dibuktikan oleh responden pada penelitian ini.

Menghindari kesendirian sangat penting bagi penderita skizofrenia karena banyak di antara penderita skizofrenia yang mengalami halusinasi ketika mereka sendirian dan tidak ada kegiatan (Hayashi, Igarashi, Suda, \& Nakagawa, 2007; Tsai \& Chen, 2005). Kesendirian membuat penderita melamun dan hal tersebut dapat merangsang munculnya halusinasi. Merawat penderita skizofrenia yang mengalami halusinasi sangatlah penting untuk melibatkan penderita skizofrenia dalam berbagai kegiatan sehingga tidak ada waktu bagi penderita untuk sendiri dan melamun.

Mengendalikan pikiran dapat dijelaskan dengan teori cognitive behavioristic yang dipelopori oleh Aaron T Beck. Seseorang berperilaku tertentu sesuai dengan apa yang dipikirkannya dan penting untuk melatih penderita untuk berpikiran positif serta melupakan kejadian-kejadian yang menyakitkan dalam hidupnya.

Responden dalam penelitian ini mengungkapkan bahwa dirinya tidak ingin menekan perasaan. Hal ini berarti boleh menggunakan mekanisme koping yang tidak konstruktif yaitu represi (menekan perasaan ke alam bawah sadar). Perasaan yang tertekan tersebut menyebabkan individu stres (Frisch $\&$ Frisch, 2006). Keadaan stres pada penderita skizofrenia yang mengalami halusinasi dapat mencetuskan halusinasinya (Frisch \& Frisch, 2006). Respons tersebut mengandung makna bahwa responden tidak ingin menggunakan 
Suryani: Pengalaman Penderita Skizofrenia

mekanisme koping yang tidak konstruktif

\section{Simpulan}

Penelitian ini merupakan penelitian kualitatif yang bertujuan mengungkap pengalaman individu yang didiagnosis skizofrenia tentang terjadinya halusinasi. Hasil penelitian ini menunjukkan bahwa terjadinya halusinasi berhubungan erat dengan beratnya masalah yang dipersepsikan oleh individu dan koping yang dimilikinya untuk mengatasi masalahnya. Selain itu kejadian halusinasi berikutnya dicetuskan oleh kejadiankejadian tertentu dalam kehidupan individu yang biasanya menganggu perasaan dan pikirannya.

Hasil penelitian ini diharapkan dapat dijadikan basis intervensi keperawatan dalam merawat klien yang mengalami halusinasi, sehingga tidak terpaku hanya pada langkahlangkah intervensi yang sudah biasa digunakan di lapangan.

\section{Daftar Pustaka}

Antai-otong, D. (1995). Psychiatric nursing : Biological and behavioral concept. Philadelphia: WB Saunders Company.

Behrendt, R., and Young, C. (2004). Hallucinations in schizophrenia, sensory impairment, and brain disease: A unifying model. Behavioural and Brain science, 27 (6), 771-830.

Carpenter, T. (2004). Clinical constructs and therapeutic discovery. Schizophrenia Research, $72,69-73$.

Elder, R., Evans, K. \& Nizette, D. (2005). Psychiatric and mental health nursing, NSW: Elsevier.

Frisch, N.C. and Frisch, L (2006). Psychiatric Mental Health nursing (3rd ed.) Canada: Thompson Delmar Learning.

Garcelan, S.P. (2004). A psychological model for verbal auditory hallucinations. International Journal of Psychology and Psychological
Therapy, 4(1), 129-153.

Giorgi,A\& Giorgi,B. (2008). Phenomenology in J.A. Smith (Eds.). Qualitative psychology: A practical guide to research method (pp.26-51). London: Sage publications.

Hayashi, N., Igarashi, Y., Suda, K., \& Nakagawa, S. (2007). Auditory hallucination coping techniques and their relationship to psychotic symptomatology. Psychiatry and Clinical Neurosciences, 61, 640-645.

Mohr, S., Brandt, P. Y., Borras, L., Gilliéron, C., \& Huguelet, P. (2006). Toward an integration of spirituality and religiousness into the psychosocial dimension of schizophrenia.

O'Daly, o.G., Frangon, S., Chitnis, X., \& Shergill, S.S. (2007). Brain structural changes in schizophrenia patients with persistent hallucinations. Psychiatry Research: Neuroimaging, 156, 15-21.

Rossler, W., Salize, H.J., van Os, J., \& Riecher-Rossler, A. (2005). Size of burden of schizophrenia and psychotic disorders. European Neuropsychopharmacology, 15, 399-409.

Shawyer, F., Mackinnon A., Farhall J., Sims E., Blaney S., Yardley P., Daly M., Mullen P. \& Colopov D. (2008). Acting on harmful command hallucinations in psychotic disorders. The Journal of Nervous and Mental Disease, 196 (5), 390-398.

Tsai, Y. \& Chen, C. (2005). Self-care symptom management strategies for auditory hallucinations among patients with schizophrenia in Taiwan. Applied Nursing Research, 19(4), 191-196.

Uhlhass, P.J. \& Mishara, A.L. (2006). Perceptual anomalies in schizophrenia: Integrating phenomenology and cognitive neuroscience. Schizophrenia Bulletin, 33(1), 142-156.

Whitfield, C., Dubeb, S., Felitti, V. \& Anda, R. (2005). Adverse childhood experiences 
Suryani: Pengalaman Penderita Skizofrenia

and hallucinations. Child Abuse \& Neglect, 29, 797-810.

Wilding, C. \& Whiteford, G. (2005). Phenomenological research: An exploration of conceptual, theoretical and practical issues. OTJR: Occupation, Participation and
Health, 25(3), 98-104.

WHO (2008). Mental health and substance abuse: facts and figures. Retrieved May 25, 2009, from http://www.searo.who.int/en/ section1174/section1199/section1567 6744 . htm. 